Doi: https://doi.org/10.31578/jebs.v6i1.223

\title{
The Role of Emotional Intelligence in the EFL Classroom: Reflections of EFL Teachers
}

\author{
Ismail Alrefaai*
}

Sayed Ali Shah ${ }^{* *}$

\begin{abstract}
Several studies have suggested that teachers' Emotional Intelligence (EI) is essential for teacher effectiveness. Also, there has been increasing recognition of the importance of social-emotional competencies to students' learning and academic achievement. This paper sheds light on the role of El training in the EFL classroom by examining and analysing several research articles related to EI with particular emphasis on the role of El in EFL contexts. The reviewed literature on the topic reveals the importance of El for EFL teachers and students and the need for providing training courses for EFL teachers to help them understand and manage their feelings and the feelings of students, parents, and administrators.
\end{abstract}

Keywords: Emotional intelligence, EFL teachers, language learning, professional development, teaching English

\section{Introduction}

Most universities focus greatly on academic attainment, while little attention is given to the affective domain in English teaching programs. Although academic achievement is significant, other areas such as teachers' and students' feelings should not be ignored. Hence comes the importance of emotional intelligence (EI) and its significant role in the learning-teaching process. In addition to catering for learners' intellectual abilities and academic achievement, it is also the responsibility of educational institutions to help teachers and students become skilful in dealing with the emotional challenges they may face inside and outside their schools.

The term El became famous when Daniel Goleman claimed that El is more important than IQ (Goleman, 1996). Additionally, literature related to emotional intelligence has shown that human beings attribute $80 \%$ of their success to El and $20 \%$ of their success to IQ (Kirch, Tucker, \& Kirch, 2001).

Many researchers (e.g., Elias et al., 1997; Greenberg et al., 2003; Stein \& Book, 2000; Haskett, 2003; Drew, 2006; Bora, 2012) conclude that El is linked to learning, academic achievements among students, and effective teaching practices. Salovey and Mayer (1990) have provided valuable insights into the role of emotional intelligence in teaching and learning. Similarly, Pishghadam (2009) has explored the vital role of emotional intelligence in students' academic scores in reading, listening, writing, and reading. His study reveals that second language learning is strongly associated with several dimensions of emotional intelligence. Furthermore, Mohzan, Hassan and Halili (2013) suggest that emotional intelligence can improve academic and educational achievements. In this direction, Zarezadeh (2013) has investigated the function of emotional intelligence in learning English. The findings show that there is a strong correlation between emotional intelligence, speaking, reading, and intrapersonal skills. In another research, Shao, Yu and Ji (2013) have investigated the relationship between EFL students' emotional intelligence

* English Department, Faculty of Languages and Translation, King Khalid University, Saudi Arabia

** English Department, Faculty of Languages and Translation, King Khalid University, Saudi Arabia 
and writing achievement among 68 non-English major freshmen in a university in Hang Zhou. They have found a relatively strong positive relationship between El and writing achievement. Nevertheless, more attention is required to determine the ways which could help raise foreign language learners' emotional intelligence.

According to Ensari (2017), the importance of emotional intelligence can be attributed to the following factors:

- El affects a person's attitude and outlook on life.

- El helps in decreasing anxiety and depression.

- El has a high effect on social relationships.

- High El helps people to communicate with others more effectively.

- High El helps people to reduce procrastination and increase self-confidence.

EFL students, in their endeavour to learn English, often interact with their classmates and instructors. Subsequently, they face emotional challenges that need to be addressed in a classroom environment. Also, in order to be highly effective, EFL teachers should be proficient in dealing with students' emotions and feelings. This situation motivated the authors to review relevant literature on the role of emotional intelligence in the EFL classroom.

\section{The Notion of Emotional Intelligence}

The concept of emotional intelligence has highlighted the relationship between emotions, thinking, and performance in the classroom. Several scholars have suggested that teachers' El competencies are particularly crucial for teacher effectiveness (e.g., Hassan et al., 2015; McCown, Jensen, \& Freedman, 2007). Salovey and Mayer (1990) defined emotional intelligence as "a type of social intelligence that involves the ability to monitor one's own and others' emotions, to discriminate among them, and to use the information to guide one's thinking and actions" (p. 186). Similarly, Goleman (1998) defined El as "the capacity for understanding our feelings and those of others, for motivating others and ourselves whilst using leadership, empathy, and integrity" (p. 82). According to Salovey et al. (2004), El is made up of three critical emotional factors: (a) the ability of an individual to perceive emotions, (b) the ability of an individual to compare emotions and feelings, and (c) the ability of an individual to control personal emotions and influence the emotions of another person.

Goleman's (1995) El original model includes five domains: knowing one's emotions, managing emotions, motivating oneself, recognizing emotions in others, and handling relationships. Knowing one's emotions is also known as intrapersonal skills that individuals possess and use when managing their feelings and behaviours. Managing emotions is also called interpersonal skills which individuals use when dealing with other individuals.

It is important to note that Goleman broadened Salovey and Mayer's definition by including motivation as a factor in El. As motivation has different components such as desire, interest, attitude, etc., it plays a significant role in foreign language teaching and learning. According to Richards and Schmidt (2002), motivation "is generally considered to be one of the primary causes of success and failure in second language learning" (p. 343). The importance of El in all fields of life motivated researchers to deal with the question of El development.

In order to improve El of educators, it is imperative to understand the levels of emotions. Machera and Machera (2017) suggest that there are three levels of emotions: low emotions, moderate emotions, and high emotions. Low emotions are 
acceptable; moderate emotions are moderately acceptable, but high emotions are not acceptable. When the emotions are high, it is recommended to reduce them to a lower level.

Dulewicz and Higgs (2004) have found that it is possible to develop El taking a training action that develops interpersonal and intrapersonal skills. Myers and Tucker (2005) believe that there are several ways to learn and develop El, the most prominent of which is through training. On the other hand, Tucker et al. (2000) have found that individuals can learn El through their experiences. Using experiential exercises with a focus on El, business graduate students managed to enhance their El scores (Tucker et al., 2000). Furthermore, El can be improved throughout a person's life. "The skills for emotional intelligence may be developed throughout someone's life as they are part of lifelong learning, and this forms the foundation for a balanced lifestyle" (Machera \& Machera, 2017, p. 461).

Koç (2019) has found that there is a strong correlation between emotional intelligence and self-directed learning readiness. Furthermore, it is possible to predict self-directed learning readiness through emotional intelligence. Also, Saud (2019) has described the level of emotional intelligence among Saudi EFL undergraduate students and the impact of emotional intelligence on achievement in learning English as a foreign language. The results have shown that Saudi EFL students at King Khalid University have a high level

of emotional intelligence. Additionally, the findings have revealed that "utilization of emotion and "management of others emotion", as two subscales of emotional intelligence, have a strong correlation with the level of achievement in English. Additionally, Stankovska et al. (2018) have investigated the relationship between emotional intelligence, test anxiety and academic stress. The results have indicated that there is a correlation between total score of emotional intelligence, test anxiety and academic stress, as well as academic success. At the same time there has been a significant positive relationship between emotional intelligence, test anxiety, academic stress and gender. Also, the results have shown that emotional intelligence, test anxiety and academic stress predict university students' academic achievement.

Given the fact that individuals can develop El, it would be beneficial to research the activities that can help professionals improve their El in a workplace context. Salovey and Mayer (1990) state that individuals may develop their emotional intelligence through:

- Utilizing good nonverbal communication: eye contact, facial expression, tone of voice and posture and gesture;

- Using humour and laughter;

- Seeing work as play;

- $\quad$ Staying focused;

- Choosing/selecting the right words;

- Learning to forgive;

- Finding strategies to reduce high emotions (take a walk, do the shopping, watch cartoons, do gardening, and any other activities besides formal working).

All the above-mentioned factors help students to perform better and lead to a more successful personal and professional life. "The more the students learn about reducing high emotions, the better they perform in their academic subjects" (Machera \& Machera, 2017, p. 461). Hence, it can be concluded that developing El competencies can play a significant role in the EFL classroom. 


\section{El in the EFL Classroom}

As shown above in the literature review, several studies (e.g., Pishghadam, 2009; Shao, Yu, \& Ji, 2013) have revealed a positive correlation between El and language learning. Arnold (1999) attributed the importance of affect and emotion in the realm of education to two reasons:

1. Attention to the affective dimension can lead to more effective language learning.

2. This attention to affective factors can even reach beyond language teaching and even beyond what has traditionally been considered the academic realm.

According to Garrett and Young (2009), "affect and emotion are concepts that have been in the shadows of discussion of classroom foreign language learning, where the primary focus has been on the development of knowledge and use of new language" (p.209). In the EFL context, it is worth mentioning that the humanistic approach in language teaching does not focus only on the learner's intellect; it stresses the importance of feelings and emotional needs as well. This humanistic philosophy subsumes four language teaching methods, namely: The Silent Way, Community Language Learning, Desuggestopedia, and Total Physical Response.

In the Silent Way, the teacher always tries to find ways to help students overcome negative feelings. For instance, teachers allow students to express their opinions at the end of each lesson, and teachers take into consideration what students say. Also, students are encouraged to work together; subsequently, such cooperative learning activities create a conducive learning environment that leads to better teaching and learning outcomes (Larsen-Freeman \& Anderson, 2011, p.113).

In Community Language Learning, students are always invited to comment on how they feel. The teacher plays an essential role in understanding students' feelings and helps them overcome negative emotions, which may hinder their learning ((Larsen-Freeman \& Anderson, 2011, p.149).

One of the main principles of Desuggestopedia is that "if students are relaxed and confident, they will not need to try hard to learn the language. It will just come naturally and easily" (Larsen-Freeman \& Anderson, 2011, p. 113). In this method, negative feelings are called psychological barriers that stand in the path of language learning. Therefore, it is the responsibility of the teacher to remove these barriers to help students learn the foreign language in a collaborative learning environment. It is possible to remove these barriers through direct and indirect positive suggestions that bolster students' self-confidence and convince them that success is achievable.

The Total Physical Response was developed to reduce the stress language learners face. Therefore, students are required to speak only when they are ready to speak. Moreover, creating an enjoyable atmosphere in the classroom relieves anxiety and motivates students to learn in a better way (Larsen-Freeman \& Anderson, 2011, p.163).

To reduce anxiety and motivate students, the humanistic approach in language teaching utilizes several techniques, such as the use of posters, charts, music, and realia. In addition, a language classroom usually has comfortable and moveable chairs, and learners are often encouraged to ask questions in the target language. Besides, language learners do peer work, play games, perform role plays, and participate in creative writing activities. According to Prabhavathy and Mahalakshmi (2012), "active participation helps in the learning of new material. Role play (fantasy) reduces the threat, and so barriers to learning can be overcome" (p.39).

The above-mentioned practices of humanistic methodologies can be used by learners of language skills in the EFL classroom environment. Prabhavathy and Mahalakshmi (2012) state that if humanistic methodologies are employed effectively, 
EFL students will learn the language very effectively. In these situations, EFL teachers can play a very significant role to involve students in meaningful activities that would contribute to their learning outcomes.

\section{El and EFL Teachers}

According to Ensari (2017), as figure 1 below shows, emotional intelligence subsumes four branches: perceiving emotions, using emotions to facilitate thought, understanding emotions, and managing emotions.

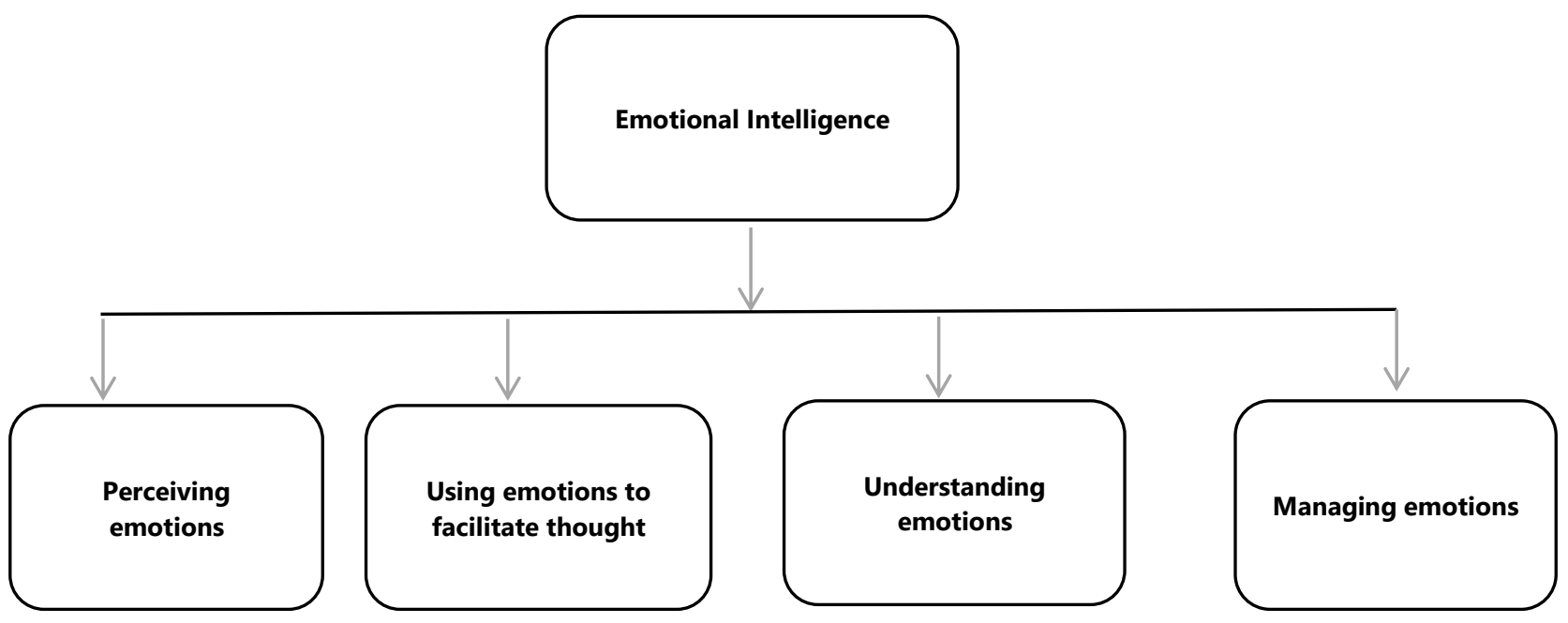

Figure 1: The four branches of emotional intelligence

EFL teachers experience a wide range of positive and negative emotions while teaching and interacting with students. They need to deal with their own emotions and the emotions of their students as well. Therefore, they require training in the field of emotional intelligence so they can create a supportive and productive learning environment. Koç states that the "implementation of emotional training will result in better achievement and better self-directed learning readiness for learners. That is why, El training should be included in the curriculum." (Koç, 2019, p. 681).

In the EFL classroom, teachers need to perceive learners' emotions, especially their nonverbal expressions. The ability to perceive learners' emotions is one of the essential skills every language teacher should acquire. Furthermore, emotions can be used to facilitate and promote thinking. Therefore, language teachers can creatively utilize emotions to help EFL learners acquire high-order-thinking skills. Additionally, understanding emotional messages plays a very significant role in the EFL classroom environment. For instance, certain facial expressions may indicate that a learner is either confused or needs help from the teacher. Such emotional messages, if neglected, might lead to negative attitudes and demotivation among the EFL students.

Furthermore, social relations can be utilized to bolster El in EFL classrooms. Ensari (2017) states that "an individual who has high El has better social relations, can solve emotional problems quicker and easier than others, is strong in verbal, social and other intelligences, is less apt to engage in problematic behaviours, and avoids self-destruction and negative behaviours such as smoking, drug abuse and violence" (p. 212). For optimal teaching outcomes, EFL teachers can use many teaching techniques such as pair and group work, discussions, debates, projects, presentations, and many other techniques to enhance social relations among students in the EFL classroom.

In addition, EFL teachers need to recognize non-verbal behaviours for two main reasons: (a) non-verbal behaviours reflect our feelings and (b) they play a significant role in communication. Ensari (2017) argues that "recognizing non-verbal behaviours 
that reflect our emotions is a critical component of communication" (p. 212). For example, when a student feels confused because he/she does not understand something, she/he may express his/her anxiety by using facial expressions, such as the widening of the eyes or shaking of the head. If the teacher understands such anxiety and confusion through the observation of students' facial expressions, this is an indication that the teacher has high El.

It has been argued that emotionally intelligent teachers would demonstrate care, create an emotional climate that enhances the learning environment, and be more effective in achieving the academic goals they set for themselves (Coetzee \& Jansen, 2007; Ramana, 2013). Besides, teachers' emotions affect their well-being, motivation, energy levels and creativity, job satisfaction, social relationships, and teaching and learning processes. These, in turn, strongly impact upon students' feelings and achievement.

\section{Directions for Future Research in the Saudi EFL Context}

The reviewed literature in this paper signifies the vital role of El in the process of English language teaching and learning, specifically in EFL contexts. It has been established that El, not only in mainstream education but in EFL/ESL context can contribute to improved teaching and learning outcomes. Hence, it is important that language teachers develop their own emotional intelligence and learn more about teaching strategies that can instill El in language learners. It is equally important for the students to be emotionally intelligent in a classroom environment in order to perform various roles and actively partake in classroom activities. Nevertheless, there seems to be a serious dearth of empirical evidence on this topic in the Saudi EFL context that calls for more research in this direction (Saud, 2019).

Since Saudi EFL institutes across the kingdom have language teachers from various countries around the world, their improved El will add to their self-efficacy and learners' effectiveness. EFL teachers with diverse language and cultural backgrounds will be better equipped to understand the learners' learning needs and institutional and social expectations in their workplace. Therefore, it is important that educational institutions in Saudi Arabia offer training opportunities to teachers to help them develop their El in a guided fashion. Such professional learning activities can be supported through research and changes can be made in the light of the findings to sustain teacher development in the area of El.

Future research can consider the notion of El from teachers' as well as students' perspectives to bring forth the perceptions, understanding and needs of both the stakeholders in EFL classrooms. A variety of teaching methods can be explored in a classroom setting to see their effectiveness in relation to the application of El. Furthermore, numerous data collection tools can help researchers to gather rich, diverse and more reliable data that would give a comprehensive understanding of the research phenomenon

\section{Conclusion}

El plays a crucial role in teaching English. This role can be attributed to the strong positive correlation between El and success in learning English (Zarezadeh, 2013). Furthermore, El can be improved through training and professional learning courses for teachers. Therefore, it is for educational institutions to start training programs for EFL teachers to enable them to deal with their emotions and the feelings of their students. These pre-service and in-service programs should become part and parcel of teachers' preparation programs. Qualified EFL teachers can manage the feelings of their students and facilitate the learning-teaching process through the use of eye contact, facial expressions, tone of voice, humour, laughter, and finding strategies to reduce the impact of high emotions. 
Moreover, it is imperative to raise the awareness of concerned parents of the crucial role of El. When parents become aware of the significance of $\mathrm{El}$, they will also try to cultivate El among their children and help them become successful learners.

To conclude, there is a need to conduct further empirical studies related to the role of El in the EFL classroom with particular emphasis on certain variables such as level of students, gender, motivation, and teachers' training. Also, educational institutions should not merely focus on students' intellect and academic achievement; other areas like physical activists, feelings, and emotions should also be considered. 


\section{References}

Arnold, J. (1999). Affect in Language Learning. Cambridge: Cambridge University Press.

Bora, F.D. (2012). The Impact of Emotional Intelligence on Developing Speaking Skills: From Brain-based Perspective. EFL Learning, 5(4), 120-123. https://doi.org/10.1016/j.sbspro.2012.05.434

Coetzee, M. \& Jansen, C.A. (2007). Emotional Intelligence in the Classroom: The Secret of Happy Teachers. Cape Town: Juta

Drew, T.L. (2006). The Relationship between Emotional Intelligence and Student Teacher Performance. Doctoral dissertation. Lincoln: University of Nebraska.

Dulewicz, V. \& Higgs, M. (2004). Can emotional intelligence be developed? International Journal of Human Resource Management, 15, 95-111. doi: $10.1080 / \quad 0958519032000157366$

Elias, M.J., Zins, J.E., Weissberg, R.P., Frey, K.S., Greenberg, M.T., Haynes, N.M., Kessler, R., Schwab-Stone, M.E., \& Shriver, T.P. (1997). Promoting Social and Emotional Learning: Guidelines for Educators. Alexandria, VA: ASCD.

Ensari, P. (2017). How to improve emotional intelligence and social skills among adolescents: The development and test of a new micro expressions training. Journal of Behavioral and Brain Science, 7, 211-225.

Garrett, P., \& Young, R. (2009). Theorizing affect in foreign language learning: An analysis of one learner's responses to a communicative-based Portuguese course. The Modern Language Journal, 93, 209-226.

Goleman, D. (1998). Working with Emotional Intelligence. London: Bloomsbury.

Goleman, D. (1996). Emotional intelligence. Why it can matter more than IQ. Learning, 24, 49-50.

Goleman, D. (1995). Emotional Intelligence. New York, NY: Bantam.

Greenberg, M.T., Weissberg, R.P., O'Brien, M.U., Zins, J.E., Fredericks, L., Resnik, H., \& Elias, M.J. (2003). Enhancing school-based prevention and youth development through coordinated social, emotional and academic learning. American Psychologist, $58(6 / 7), 466-474$.

Haskett, R. (2003). Emotional Intelligence and Teaching Success in Higher Education. Doctoral dissertation. Bloomington: Indiana University.

Larsen-Freeman, D. \& Anderson, M. (2011).Techniques \& Principles in Language Teaching (3rd ed.). Oxford: Oxford University Press.

Hassan, N., Hayati M.D., Jani, S., Mat Som, R., Zainie Abd Hamid, N. \& Azmaniza Azizam, N. (2015). The relationship between emotional intelligence and teaching effectiveness among lecturers at UniversitiTeknologi MARA, PuncakAlam, Malaysia. International Journal of Social Science and Humanity, 5(1), 1-5.

Kirch, D.P., Tucker, M.L., \& Kirch, C.F. (2001). The benefits of emotional intelligence in accounting firms. CPA Journal, 7(8), 60-61.

Koç, S.E. (2019). The relationship between emotional intelligence, self-directed learning readiness and achievement. International Online Journal of Education and Teaching (IOJET), 6(3), 672-688.

Machera, R.P. \& Machera, P.C. (2017). Emotional Intelligence (EI): A therapy for higher emotional intelligence (EI), therapy for higher education students. Universal Journal of Educational Research, 5 (3), 461-471, 2017. http://www.hrpub.org DOI: 10.13189/ujer.2017.050318 
McCown, K., Jensen, A.L., \& Freedman J. (2007). The self-science approach to social-emotional learning. In R. Bar-On, J.G. Maree and M.J. Elias (Eds.). Educating People to Be Emotionally Intelligent (p. 109-122). Westport, CT: Praeger.

Mohzan, M., Hassan, N., \& Halili, N. (2013). The influence of emotional intelligence on

academic achievement. Procedia-Social and Behavioral Sciences, 90, 303-312. https://doi.org/10.1016/j.sbspro.2013.07.095

Myers, L.L., \& Tucker, M.L. (2005). Increasing awareness of emotional intelligence in a business curriculum. Business Communication Quarterly, 68 (1), 44-51. doi: http://dx.doi.org/10.1177/1080569904273753

Pishghadam, R. (2009). A quantitative analysis of the relationship between emotional intelligence and foreign language learning. Electronic Journal of Foreign Language Teaching, 6 (1), 31-41.

Prabhavathy, P. \& Mahalakshmi, S. N. (2012). ELT with specific regard to Humanistic Approach. IOSR Journal of Humanities and Social Science (IOSRJHSS), 1(1), 38-39.

Ramana, T.V. (2013). Emotional intelligence and teacher effectiveness - an analysis. Voice of Research, 2 (2), 18-22.

Richards, J. \& Schmidt, R. (2002). Longman Dictionary of Teaching and Applied Linguistics. Essex: Longman Group Limited.

Salovey, P. \& Mayer, J. (1990). Emotional intelligence. Imagination, Cognition, and Personality, 9, $185-211$. https://doi.org/10.2190/DUGG-P24E-52WK-6CDG

Salovey, P., Brackett, M.A., \& Mayer, J.D. (2004). Emotional Intelligence: Key Readings on the Mayer and Salovey Model. New York, NY: Dude.

Saud, W.I. (2019). Emotional intelligence and its relationship to academic performance among Saudi EFL undergraduates. International Journal of Higher Education, 8(1), 222-230. doi:10.5430/ijhe.v8n6p222. https://doi.org/10.5430/ijhe.v8n6p222.

Shao, K.Q., Yu, W.H. \& Ji, Z.M. (2012). The relationship between EFL students' emotional intelligence and writing achievement. Innovation in Language Learning and Teaching, 7(2), 107-124, DOI: 10.1080/17501229.2012.725730

Stankovska, G., Dimitrovski, D., Angelkoska, S., Ibraimi, Z., \& Uka, V. (2018), Emotional intelligence, test anxiety and academic stress among university students. Education in Modern Society BCES Conference Books, Volume 16. Sofia: Bulgarian Comparative Education Society

Stein, S.J. \& Book, H.E. (2000). The EQ Edge - Emotional Intelligence and Your Success. Toronto: MHS.

Tucker, M., Sojka, J., Barone, F., \& McCarthy, A. (2000). Training tomorrow's leaders: Enhancing the emotional intelligence of business graduates. Journal of Education for Business, 75, 331-337. doi: 10.1080/08832320009599036

Zarezadeh, T. (2013). The effect of emotional intelligence in English language learning. Procedia - Social and Behavioral Sciences, 84, 1286-1289. https://doi.org/10.1016/j.sbspro.2013.06.745 